\title{
Citrullus colocynthis (L.) Schrad. (colocynth): Biotechnological perspectives
}

\author{
Jaime A. Teixeira da Silva ${ }^{1 *}$, Abdullah I. Hussain ${ }^{2}$ \\ ${ }^{1}$ P. O. Box 7, Miki-cho Post Office, Ikenobe 3011-2, Kagawa-ken, 761-0799, Japan, ${ }^{2}$ Department of Applied Chemistry and Biochemistry, \\ Natural Product and Synthetic Chemistry Laboratory, Government College University, Faisalabad 38000, Pakistan
}

\section{A B S T R A C T}

Citrullus colocynthis (L.) Schrad. is commonly known as colocynth. The fruit pulp of colocynth has medicinal properties while the seeds have nutritive qualities. C. colosynthis is resistant to high temperatures and grows in the desert regions of North Africa, the Middle East and Western Asia. C. colocynthis likely carries genes of interest that could be explored for inducing abiotic stress resistance in transgenic plants. Although the tissue culture and molecular biology of this species have been explored, the latter has been primarily used to resolve taxonomic relationships with other members of the Citrullus genus and curcubits. Genetic mining of the plant is scarce while genetic transformation protocols are also rare. The aim of the present review is to present a brief overview of the biotechnological perspectives of C. colocynthis.

Keywords: Abiotic stress-resistance; Colocynth; Cucurbitaceae; Medicinal properties; Plant growth regulators; Tissue culture

\section{INTRODUCTION}

Citrullus colocynthis (L.) Schrad. (Cucurbitaceae) has medicinal and ornamental purposes, the former derived primarily from the fruit pulp (de Smet, 1997). Common names for this plant include colocynth, bitter gourd, bitter apple, and bitter cucumber in English while it is known as Koloquinthe in German and coloquinte in French (de Smet, 1997). C. colocynthis has only one accepted name but six synonyms (The Plant List, 2017). In India and Pakistan, it is known as tumba (Mahajan and Kumawat, 2013; Hussain et al., 2014).

Early literature indicates that $C$. colocynthis was the closest relative or progenitor of watermelon (Citrullus lanatus (South African watermelon) and Citrullus vulgaris L. (Linnaeus' watermelon)) (Assis et al., 2000), but molecular phylogenetic analyses combined with herbarium sample analyses conducted by Chomicki and Renner (2015) revealed that in fact this was not true. Furthermore, what was referred to as "Egusi" melon by Ntui et al. (2009, 2010a, 2010b) as Colocynthis citrullus L., may represent an incorrect inversion of the Latin name and possibly a completely different plant, since Chomicki and Renner (2015) indicated that "Egusi" melon is Citrullus mucosospermus (formerly
C. lanatus subsp. mucosospermus; Levi and Thomas, 2005), a position supported by morphological and phenetic analyses (Achigan-Dako et al., 2015) and genetic studies (Paris, 2016) (Table 1). Jarret and Newman (2000) also showed that C. colocynthis and C. mucosospermus clustered separately using internal transcribed spacer (ITS) sequences. Until formally resolved, for all effective purposes, the authors consider, within this review, the plant reported by Ntui et al. (2009, 2010a, 2010b) to be C. colocynthis.

Dane et al. (2007) employed three cpDNA regions and the nuclear G3pdh transit peptide section with intron 2 in a using molecular phylogeography study to show how C. colocynthis accessions migrated from xerophytic habitats in Algeria, Chad and Egypt to Israel, Cyprus and the Middle East, then further east to Iran, Afghanistan, Pakistan, and India, whereas Moroccan accessions migrated to Australia while Israeli accessions migrated to Ethiopia.

\section{IMPORTANCE AND USES}

According to Hussain et al. (2014), C. colocynthis has the following traditional medicinal uses: "diabetes, leprosy, common cold, cough, asthma, bronchitis,

\footnotetext{
*Corresponding author:

Jaime A. Teixeira da Silva, P. O. Box 7, Miki-cho Post Office, Ikenobe 3011-2, Kagawa-ken, 761-0799, Japan. E-mail: jaimetex@yahoo.com

Received: 29 November 2016;

Revised: 30 January 2017;

Accepted: 31 January 2017;

Published Online: 05 February 2017
} 
Table 1: Taxonomy of Citrullus colocynthis (L.) Schrad*

Tanonomy and classification of Citrullus colosynthis (Renner et al. 2014; Chomicki and Renner, 2015)
Citrullus colocynthis var. capensis Alef.
Citrullus colocynthis var. insipidus Pangalo
Citrullus colocynthis subsp. insipidus (Pangalo) Fursa
\begin{tabular}{ll} 
Citrullus colocynthis var. lanatus (Thunb.) Matsum. \& Nakai \\
Citrullus colocynthis var. stenotomus Pangalo \\
Citrullus colocynthis subsp. stenotomus (Pangalo) Fursa \\
\hline English name & Species \\
\hline Dessert watermelon & C. lanatus (Thunb.) Matsum. \& Nakai \\
Citron watermelon & C. amarus Schrad. \\
Egusi watermelon & C. mucosospermus (Fursa) Fursa \\
Colocynth & C. colocynthis (L.) Schrad.
\end{tabular}

*Synonyms from The Plant List (2017), and within the Citrullus genus, based on Paris (2016)

jaundice, joint pain, cancer, toothache, wound, mastitis, and in gastrointestinal disorders such as indigestion, constipation, dysentery, gastroenteritis, colic pain and different microbial infections." Also, according to the same authors, who wrote a comprehensive review on several properties of C. colocynthis, indicated that there are multiple medicinal and biological activities, including antidiabetic, anticancer, cytotoxic, antioxidant, antilipidemic, insecticidal, antimicrobial and anti-inflammatory. De Smet (1997) also reviewed earlier literature on the medicinal properties of C. colocynthis.

The seeds of C. colocynthis contain edible oil, $56 \%$ of which contained linoleic acids and $25 \%$ of which contained oleic acids (Sawaya et al., 1983). Fruits hold bioactive chemical constituents such as glycosides, flavonoids, alkaloids and terpenoids while "curcurbitacins A, B, C, D, E, I, J, K, and $\mathrm{L}$ and Colocynthosides $\mathrm{A}$, and $\mathrm{B}$ " have also been isolated (Hussain et al., 2014). Several accessions have shown resistance to several viruses and diseases (Dabauza et al., 1997). The identification of such genes would assist in breeding virus and disease resistance in other cucurbits such as watermelon. To this end, Dabauza et al. (1997) developed an Agrobacterium tumefaciens-mediated genetic transformation protocol in which 7-day-old seedling cotyledons were infected with strain LBA4404 carrying the binary vector $\mathrm{pBI} 121$, harboring the $\beta$-glucuronidase (gus; reporter) and the neomycin phosphotransferase (nptII; marker) genes. Based on GUS expression, 14\% of explants were shown to be transformed. PCR confirmed the integration of the gus and nptII genes while Southern blot analysis conferred transmission of the gus gene to several transgenic plants obtained by selfing.

C. colocynthis is able to withstand extreme desert temperatures through a high rate of transpiration to lower leaf temperatures below lethal temperatures (Althawadi and Grace, 1986). In the Thar Desert in Pakistan, the perennial plant develops an extensive root system, and despite only receiving only $35-40 \mathrm{~mm}$ of rainfall per hectare, can produce as much as 1-1.5 t of seed, but as much as 40-fold more if rainfall is high (Mahajan and Kumawat, 2013). Exploring this ability of C. colocynthis to grow in arid climates, Schafferman et al. (2001) assessed 28 accessions growing wild in Negev, Arava and Sinai Deserts in Israel, and found that the mean seed oil yield ranged from $17.1 \%$ to $19.5 \%(\mathrm{v} / \mathrm{w})$ in five high-yielding lines (dry seed weight basis). In addition, across the 28 accessions, linoleic acid (C18:2) was dominant $(\overline{\mathrm{x}}=70.1 \%)$, followed by oleic acid $(\mathrm{C} 18: 1 ; \overline{\mathrm{x}}=13.1 \%)$, palmitic acid $(\mathrm{C} 16: 0 ; \overline{\mathrm{x}}=10.1 \%)$, and stearic acid (C18:0; $\overline{\mathrm{x}}=6.7 \%)$. With a seed yield of $1.5-2.1 \mathrm{~kg} / 10 \mathrm{~m}^{2}$, C. colocynthis may be a potential seed oilyielding plant for desert and arid regions (Schafferman et al., 2001).

C. colocynthis seeds exhibit strong dormancy, and even strong chemical or physical treatments are unable to release the seeds from this state of dormancy (Koller et al., 1963; El-Hajzein and Neville, 1993), although scarification of the testa using sandpaper resulted in $61 \%$ germination (Saberi and Shahriari, 2011). Mahajan and Kumawat (2013) observed 51.4\% germination of seeds taken from fresh fruits and placed at $30^{\circ} \mathrm{C}$ and $95 \%$ relative humidity whereas $48 \mathrm{~h}$ fermentation increased germination to $58.8 \%$, and decreased to $16.4 \%$ after storage for 12 months at room temperature. Sen and Bhandari (1974) achieved 98\% germination after $4.5 \mathrm{~h}$ of treatment with concentrated sulphuric acid and germination in the dark since exposure to light inhibited germination.

\section{TISSUE CULTURE AND GENETIC TRANSFORMATION}

The success of a plant genetic transformation protocol involves a reliable in vitro regeneration protocol (except for in planta transformation), an effective vector to transmit the desired gene into target tissue, stable integration and transgene expression without transgene silencing and only as a single gene copy (Teixeira da Silva et al., 2016). 
As described next, the first aspect, i.e., effective in vitro regeneration protocols, have been developed for $C$. colocynthis and tissue derived from in vitro plantlets is available all-year round and is suitable for both Agrobacterium-mediated and bombardment-induced introduction of transgenes.

There have not been many studies published on the tissue culture of C. colocynthis (Table 2). Dabauza et al. (1997) induced callus and shoots from seedlings' cotyledons, with $81.1 \%$ of explants being organogenic, and $68.3 \%$ forming shoots, $80 \%$ of which could root on IBA-containing medium. El-Baz et al. (2010) also used seedling tissue to induce callus, mostly from stems, less so from leaves and least from roots, but in all cases with more than $90 \%$ of explants inducing callus from one tissue or another. Verma et al. (2013) used disinfected shoot buds and nodes from wild plants to induce shoots (as many as 18-20/explant) and roots.

Ntui et al. (2009) induced shoots from cotyledon explants within 12 days (4.4 shoots/explant in 'NHC1-130') but hypocotyl explants failed to form shoots and only induced callus. In 'Ejagham', 86.3\% of explants induced shoots, similar to improved cultivar NHC1-130. Averaged across all four cultivars, $65 \%$ of shoots rooted on PGR-free MS medium, and although acclimatized plants had a normal appearance, in vitro, mixoploid and tetraploid shoots formed. This regeneration protocol served as the basis for genetic transformation experiments by Ntui et al. (2010b) in which cotyledonary explants of 'Ejagham' and 'NHC1-130' were infected with Agrobacterium tumefaciens strain EHA101 harboring one of two plasmids, pIG121-Hm, carrying the gus, hygromycin phosphotransferase $(h p t)$ and $n p t I I$ genes, or pBBRacdS, harboring the same three genes as well as the 1-aminocyclopropane-1-carboxylate (ACC) deaminase gene. Based on PCR of kanamycin-resistant shoots, transformation efficiency ranged from $2.4 \%$ to $9.9 \%$, depending on the cultivar and bacterial strain. Expanding upon this protocol, Ntui et al. (2010a) introduced the chimeric defensin gene from Wasabia japonica into cotyledons of 'Ejagham' and 'NHC1-130' using A. tumefaciens strain EHA101 with plasmid pEKH1-WD, with a $25-27 \%$ transformation efficiency. Transformed plats were seen to be growing in medium in which heavy fungal contamination was observed.

Meena et al. $(2010,2014)$ induced as many as 23 shoots per shoot tip. Savitha et al. (2010a, 2010b), Shasthree et al. (2012, 2014) and Ramakrishna and Shasthree (2016) noted that seedling-derived leaves formed callus more than stems (65\% vs $45 \%$ of explants) while stems formed shoots more than leaves ( $75 \%$ vs $51 \%$ of explants). Satyavani et al. (2011a) induced shoots indirectly from callus, which was induced from stem explants and a maximum of 20 shoots/explant could be induced. Taha and Mutasher
(2014) also found that seedling-derived leaves and stems were effective (induced in 83 (leaves) - 85\% (stems) of explants) explants for callus induction. Gharehmatrossian (2015) induced shoots indirectly from callus that had been induced from seedling explants, but the outcome was not quantified. More details of these studies may be found in Table 2. Shasthree et al. (2009) found that in vitro-derived regenerants showed considerable somaclonal variation, including of leaves, flowers, fruits and seeds.

\section{MOLECULAR BIOLOGY AND ABIOTIC STRESS TOLERANCE}

Molecular biology in C. colocynthis research has primarily been used in taxonomic and phylogenetic classification through the use of molecular markers while considerable work has been done on the characterization of genes and transcription factors involved in abiotic stress tolerance.

Alatar et al. (2012) optimized a protocol for the isolation of high-quality DNA from C. colocynthis from Saudi Arabia. The extracted DNA was totally digestible with $1 \mathrm{U}$ CfoI per $\mu \mathrm{g}$ DNA and showed no detectable RNA contamination, obtaining 10-20 $\mu \mathrm{g}$ DNA per tube in the $2-10 \mathrm{~Kb}$ range. This DNA is useful for plant species fragment amplification and microsatellite analysis.

The colocynth plant material used in experiments must be precise identified to avoid confusion, especially form interspecific hybrids with C. lanatus, in the field (Fulks et al., 1979), or as controlled crosses (Shimotsuma, 1960; Sain et al., 2002). However, randomly amplified polymorphic DNA (RAPD) and UPGMA cluster analyses are able to differentiate $C$. colocynthis from C. lanatus (Levi et al., 2001). RAPD was also used, alongside ISSR, to confirm the genetic stability of in vitro regenerants (Verma et al., 2013). Shaik et al. (2015) used two gene regions, the nuclear $G 3 p d h$ gene and the chloroplast $y c f 6$ - $p s b M$ intergenic spacer region, to differentiate three Citrullus species (C. colocynthis, C. lanatus (camel melon), and C. myriocarpus (prickly paddy melon)) invasive to Australia, discovering that a western and an eastern introduction of $C$. colocynthis may have taken place. Mary et al. (2016) used DNA barcoding with the trnH-psbA intergenic spacer to characterize C. colocynthis relative to other curcubit genera, placing it as a distinct phylum. Molecular markers thus serve as useful tools in taxonomic differentiation and to assess evolutionary events. Nimmakayala et al. (2011) offer a comprehensive overview of the use of molecular markers in phylogeny and taxonomy of Citrullus.

Si et al. (2009, 2010a; Table 3) found that 18 droughtresponsive genes related to abiotic and biotic stresses 


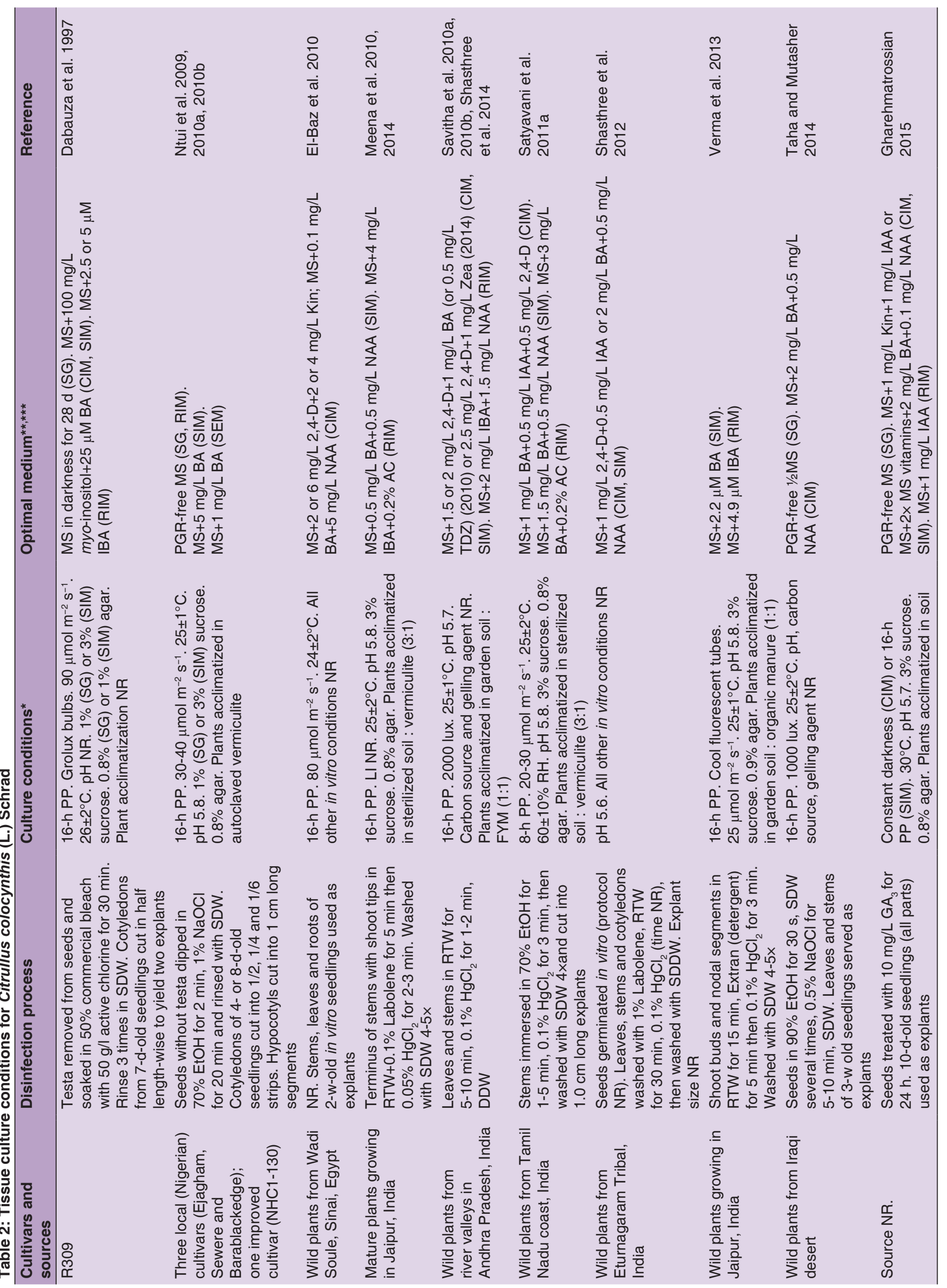




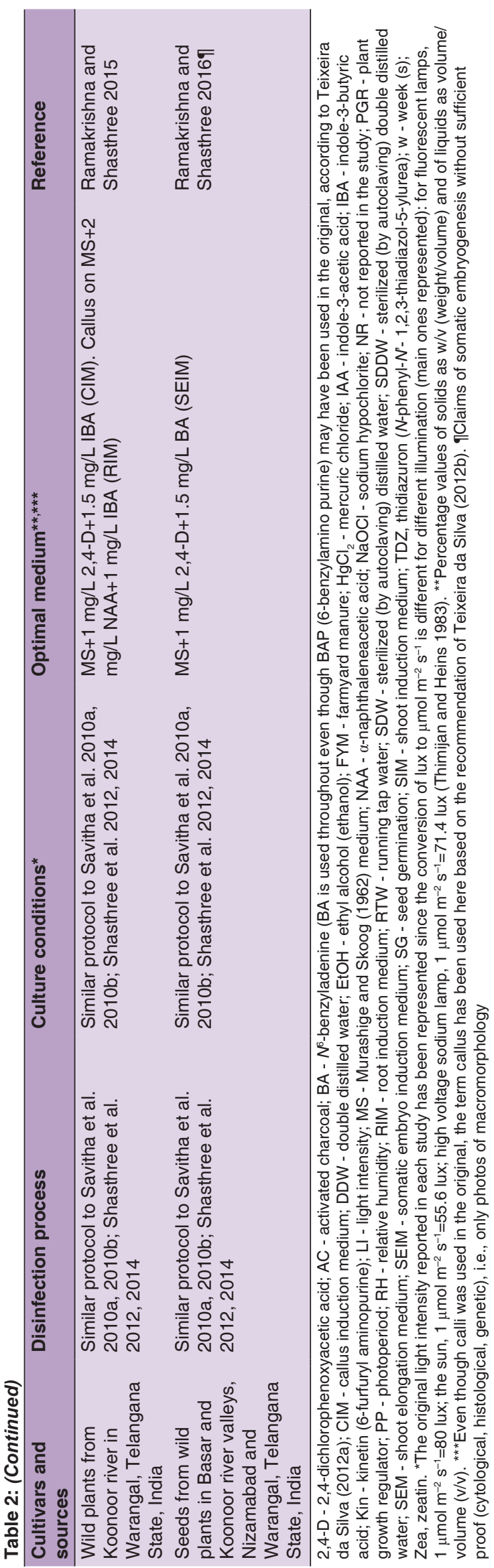

were upregulated in the shoots of seedlings of an Israeli accession in response to PEG-induced stress. Two NAC (no apical meristem, Arabidopsis transcription activation factor 1 and 2, cup-shaped cotyledon 2) transcription factors were shown to be involved in this abiotic stress response, $C c N A C 1$ and $C c N A C 2$ (Wang et al., 2014a), being influenced by the spectral light quality (Wang et al., 2014b). The ability to isolate and clone $C_{c} N A C 1$ and $C c N A C 2$ into other plants without any drought resistance might be an effective way of exploring arid and water-stressed regions for expanded horticulture with drought-resistant crops. In fact, the ability to transmit drought-resistant signals from scion to rootstock using $C$. colocynthis and watermelon (C. lanatus) (Si et al., 2010a, 2010b) holds great promise for research on the drought-resistance mechanism of C. colocynthis. Transcriptomic analyses of the leaves of C. colocynthis during drought stress revealed 2545 genes that changed significantly during drought stress (Wang et al., 2014c), giving promise to the mining of this plant for drought stress-related genes.

\section{FUTURE PERSPECTIVES}

Colocynth is a rich source of functionally important bioactive compounds and therapeutics such as polyphenols, glycosides, triterpenes and cucurbitacins and its fruit has been widely used for the treatment of many diseases including diabetes, rheumatism, paronychia, ulcer and cancer (Hussain et al., 2014). However, the biotechnology of C. colocynthis is still underexplored. Although some tissue culture studies and genetic transformation experiments exist, biotechnological research into this plant would benefit from the use of the following techniques: In vitro flowering (Teixeira da Silva et al., 2014) for controlled crosses in vitro, use of magnetic fields (Teixeira da Silva and Dobránszki, 2015), ultrasound or sonication (Teixeira da Silva and Dobránszki, 2014), or thin cell layers (Teixeira da Silva and Dobránszki, 2013) to explore alternative pathways for growth and development in vitro. Given the heat-tolerant nature of C. colocynthis (Althawadi and Grace, 1986), and ability to grow in water stress, mining the genes of this plant would perhaps reveal genes that could be cloned into other plants to induce heat stress resistance. The ability to micropropagate and mass produce uniform plant material in vitro, independent of season, or through the use of bioreactors, would allow callus to be constantly harvested for silver nanoparticle production (Satyavani et al., 2011b) with multiple uses in agriculture, medicine and industry. The cryopreservation of $C$. colocynthis seeds has already provided one such possibility for the long-term preservation of germplasm (Alsadon et al., 2014). Using callus that they had induced from the leaves of $C$. colocynthis (Satyavani et al., 2011a), Satyavani et al. (2011b) produced 
Table 3: 18 drought-responsive genes coding for functional and regulatory proteins that were differentially expressed in the roots of C. colocynthis after treatment with polyethylene glycol (modified from Si et al., 2009)

\begin{tabular}{lllc} 
Name of gene sequence & Homologous function & Homologous plant & GenBank accession number \\
\hline CC4 & Heat shock protein 70 & Cucumis sativus & FK707354 \\
CC85 & Heat shock 22 kDa protein, mitochondrial & Glycine max & GH626170 \\
CC47 & grpE like protein & Arabidopsis thaliana & GH626164 \\
CC61 & Putative pathogenesis-related protein & Cucumis sativus & GH626166 \\
CC26 & APC11 (anaphase promoting complex subunit 11) & Arabidopsis thaliana & GH626159 \\
CC36 & Putative alpha7 proteasome subunit & Nicotiana tabacum & GH626162 \\
CC37 & RBOHD (respiratory burst oxidase) & Arabidopsis thaliana & EU580727* \\
CC38 & VIP2 (VIRE2-INTERACTING PROTEIN2) & Arabidopsis thaliana & GH626163 \\
CC16 & ABC transporter-like protein & Arabidopsis thaliana & FK707355 \\
CC48 & Synaptobrevin-related protein & Pyrus pyrifolia & GH626165 \\
CC24 & Toc34-1 (translocon outer envelope of & Zea mays & GH626158 \\
& chloroplast) & & GH626167 \\
CC64 & Beta-amylase & Prunus armeniaca & GH626161 \\
CC32 & Pyruvate kinase & Arabidopsis thaliana & GH626168 \\
CC75 & TIP1 (TIP GROWTH DEFECTIVE 1) & Arabidopsis thaliana & GH626156 \\
CC19 & Leucine-rich repeat transmembrane protein & Arabidopsis thaliana & GH626157 \\
CC23 & kinase & Fagus sylvatica & GH626160 \\
CC27 & Protein kinase & Petunia x hybrida & GH626169 \\
CC76 & Hairy meristem & Glycine max &
\end{tabular}

*The Ccrboh gene in Si et al. (2010b), encoding a respiratory burst oxidase
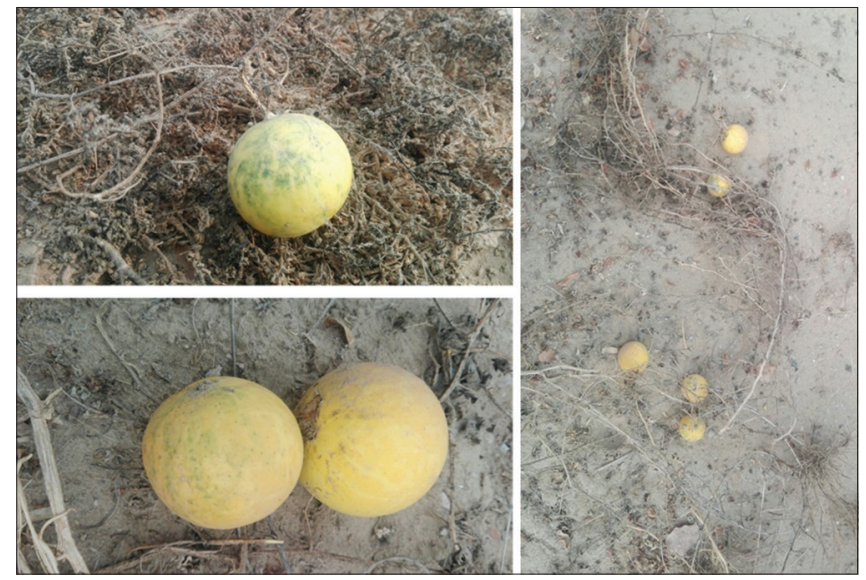

Fig 1. Colocynth (Citrullus colocynthis (L.) Schrad.) growing in a field in Faisalabad in winter (January, 2017). Despite the harsh conditions, i.e., dry, cold and arid, the plant is able to set fruit. This makes colocynth a suitable winter cash crop. All photos unpublished.

silver nanoparticles, which were able to reduce the toxicity of Human epidermoid larynx carcinoma (HEp-2) cell lines by as much as 50\%. Khan et al. (2016) purified a low molecular weight serine protease with high catalytic activity that has many possible industrial applications from C. colocynthis seeds.

\section{CONCLUSIONS}

Citrullus colocynthis (L.) Schrad., an important fruit species with medicinal and nutritional value, would serve as a valuable crop species in arid regions (Fig. 1) such as North Africa and the Middle East. To increase production, micropropagation protocols need to be refined and to fortify salt- and drought-tolerance, genetic engineering may offer a valuable solution, especially since several genes related to drought-tolerance have already been identified. Basic studies on the biology and biotechnology of this plant are needed to fortify the application of molecular marker technology, which is fairly well developed for this plant.

\section{ACKNOWLEDGEMENTS}

The authors thank Harry S. Paris (Institute of Plant Sciences, Agricultural Research Organization, Newe Ya'ar Research Center, Israel), Susanne S. Renner (Department of Biology, University of Munich, Germany) and Werner Greuter (Herbarium Mediterraneum, Orto Botanico, Italy) for fruitful and insightful discussion on taxonomic issues underlying $C$. colocynthis and the curcubits.

\section{Conflicts of interest}

The authors declare no conflicts of interest.

\section{Author contributions}

Both authors contributed equally to all parts of the development and revisions of this review.

\section{REFERENCES}

Achigan-Dako, E. G., E. S. Avohou, C. Linsoussi, A. Ahanchede, R. S. Vodouhe and F. R. Blattner. 2015. Phenetic characterization of Citrullus spp. (Cucurbitaceae) and differentiation of egusi-type (C. mucosospermus). Genet. Resour. Crop Evol. 62: 1159-1179. 
Alsadon, A. A, M. T. Sadder and A. A. M. Ali. 2014. Cryopreservation of wild bitter apple (Citrullus colocynthis L.) Seeds. Acta Hortic. 1039: 281-288.

Althawadi, A. M. and J. Grace. 1986. Water use by the desert cucurbit Citrullus colocynthis (L.) Schrad. Oecologia. 70: 475-480.

Assis, J. G. A., M. A. de Queiroz, S. M. C. de Araújo, G. Bandel and P. S. Martins. 2000. Implications of the introgression between Citrullus colocynthis and $C$. lanatus characters in the taxonomy, evolutionary dynamics and breeding of watermelon. Plant Gen. Res. Newslett. 121: 15-19.

Bankole, S. A., A. Osho, A. O. Joda and A. O. Enikuomehin. 2005. Effect of drying methods on the quality and storability of "Egusi" melon seeds (Colocynthis citrullus L.). Afr. J. Biotechnol. 4: 799-803.

Chawech, R., R. Jarraya, C. Girardi, M. Vansteelandt, G. Marti, I. Nasri, C. Racaud-Sultan and N. Fabre. 2015. Cucurbitacins from the leaves of Citrullus colocynthis (L.) Schrad. Molecules. 20: 18001-18015.

Chomicki, G. and S. S. Renner. 2015. Watermelon origin solved with molecular phylogenetics including Linnaean material: Another example of museomics. New Phytol. 205: 526-532.

Dabauza, M., M. Bordas, A. Salvador, L. A. Roig and V. Moreno. 1997. Plant regeneration and Agrobacterium-mediated transformation of cotyledon explants of Citrullus colocynthis (L.) Schrad. Plant Cell Rep. 16: 888-892.

Dane, F., J. R. Liu and C. K. Zhang. 2007. Phylogeography of the bitter apple, Citrullus colocynthis. Genet. Resour. Crop Evol. 54: 327-336.

De Smet, P. A. G. M. 1997. Citrullus Colocynthis. In: Adverse effects of herbal drugs. Volume 3 of the series adverse effects of herbal drugs, Springer, Berlin, pp. 29-36

El-Hajzein, B. and P. Neville. 1993. Etude de la germination de Citrullus colocynthis (L.) Schrad. IV. Influence de pretraitments thermiques sur la dormance des semences. Rev. Cytol. Biol. Veg. Bot. 16: 105-120.

El-Baz, F. K., A. A. Mohamed and S. I. Ali. 2010. Callus formation, phenolics content and related antioxidant activities in tissue culture of a medicinal plant colocynth (Citrullus colocynthis). Nova Biotechnol. 10: 79-94.

Fulks, B. K., J. C. Scheerens and W. P. Bemis. 1979. Natural hybridization of two Citrullus species. J. Hered. 70: 214-215.

Gharehmatrossian, S. 2015. Evaluation of callus induction and plant regeneration in Citrullus colocynthis (L.) Schrad. Iran. J. Plant Physiol. 5: 1333-1338.

Hussain, A. I., H. A. Rathore, M. Z. A. Sattar, S. A. S. Chatha, S. D. Sarker and A. H. Gilani. 2014. Citrullus colocynthis (L.) Schrad (bitter apple fruit): A review of its phytochemistry, pharmacology, traditional uses and nutritional potential. J. Ethnopharmacol. 155: 54-66.

Jarret, R.L. and M. Newman. 2000. Phylogenetic relationships among species of Citrullus and the placement of C. rehmii De Winter as determined by internal transcribed spacer (ITS) sequence heterogeneity. Genet. Resour. Crop Evol. 47: 215-222.

Khan, M. B., H. Khan, M. U. Shah and S. Khan. 2016. Purification and biochemical properties of SDS-stable low molecular weight alkaline serine protease from Citrullus colocynthis. Nat. Prod. Res. 30: 935-940.

Koller, D. A., A. Poljakoff-Mayber, A. Berg and T. Diskin. 1963. Germination regulating mechanisms in Citrullus colocynthis. Am. J. Bot. 50: 597-603.

Levi, A. and C. E. Thomas. 2005. Polymorphisms among chloroplast and mitochondrial genomes of Citrullus species and subspecies.
Genet. Resour. Crop Evol. 52: 609-617.

Mahajan, S. S. and R. N. Kumawat. 2013. Study of seed dormancy in colocynth (Citrullus colocynthis L.) With after-ripening of fruits, seed extraction procedures and period of seed storage. Natl. Acad. Sci. Lett. 36: 373-378.

Meena, M. C., R. Meena and V. Patni. 2010. High frequency plant from shoot tip explants of Citrullus colocynthis (Linn.) Schrad. - An important medicinal herb. Afr. J. Biotechnol. 9: 5037-5041.

Meena, M. C., R. Meena and V. Patni. 2014. High frequency plant from shoot tip explants of Citrullus colocynthis (Linn.) Schrad. - An important medicinal herb. J. Pharmacol. Phytochem. 2: 53-56.

Murashige, T. and F. Skoog. 1962. A revised medium for rapid growth and bioassays with tobacco tissue cultures. Physiol. Plant. 15: 473-497.

Nimmakayala, P., N. Islam-Faridi, Y. R. Tomason, F. Lutz, A. Levi and U.K. Reddy. 2011. Citrullus. In: C. Kole (Ed.), Wild Crop Relatives: Genomic and Breeding Resources, Springer-Verlag, Berlin, pp. 59-66.

Ntui, V.O., G. Thirukkumaran, S. lioka and M. Mii. 2009. Efficient plant regeneration via organogenesis in "Egusi" melon (Colocynthis citrullus L.). Sci. Hortic. 119: 397-402.

Ntui, V.O., G. Thirukkumaran, P. Azadi, R. S. Khan, I. Nakamura and M. Mii. 2010a. Stable integration and expression of wasabi defensin gene in "Egusi" melon (Colocynthis citrullus L.) Confers resistance to Fusarium wilt and Alternaria leaf spot. Plant Cell Rep. 29: 943-954.

Ntui, V. O., R. S. Khan, D. P. Chin, I. Nakamura and M. Mii. 2010 b. An efficient Agrobacterium tumefaciens-mediated genetic transformation of "Egusi" melon (Colocynthis citrullus L.). Plant Cell Tissue Organ Cult. 103: 15-22.

Ramakrishna, D., N. Muralikrishna, E. Raghu, K. Srinivas and T. Shasthree. 2015. Efficient in vitro propagation system via multiple shoot induction and assessment of clonal fidelity of regenerants in Citrullus colosynthis (L.) Schard. Plant Cell Biotechnol. Mol. Biol. 16: 108-118.

Ramakrishna, D. and T. Shasthree. 2015. Adventitious rooting and proliferation from different explants of Citrullus colocynthis (L.) Schrad an endangered medicinally important cucurbit. Asian J. Biotechnol. 7: 88-95.

Ramakrishna, D. and T. Shasthree. 2016. High efficient somatic embryogenesis development from leaf cultures of Citrullus colocynthis (L.) Schrad for generating true type clones. Physiol. Mol. Biol. Plant. 22: 279-285.

Renner, S. S., G. Chomicki and W. Greuter. 2014. Proposal to conserve the name Momordica lanata (Citrullus lanatus) (watermelon, Cucurbitaceae), with a conserved type, against Citrullus battich. Taxon. 63: 941-942.

Saberi, M. and A. Shahriari. 2011. Comparison the effect of different treatments for breaking seed dormancy of Citrullus colocynthis. J. Agric. Sci. 3: 62-67.

Sain, R. S., P. Joshi and E. V. D. Sastry. 2002. Cytogenetic analysis of interspecific hybrids in genus Citrullus (Cucurbitaceae). Euphytica. 128: 205-210.

Satyavani, K., T. Ramanathan and S. Gurudeeban. 2011a. Effect of plant growth regulators on callus induction and plantlet regeneration of bitter apple (Citrullus colocynthis) from stem explants. Asian J. Biotechnol. 3: 246-253.

Satyavani, K., S. Gurudeeban, T. Ramanathan and T. Balasubramanian. 2011b. Biomedical potential of silver nanoparticles synthesized from calli cells of Citrullus colocynthis (L.) Schrad. J. Nanobiotechnol. 9: 43.

Savitha, R., T. Shasthree, T. Sudhakar and B. Mallaiah. 2010a. High 
frequency of plantlet regeneration and multiple shoot induction from leaf and stem explants of Citrullus colocynthis (L.) Schrad, an endangered medicinal cucurbit. Int. J. Pharm. Biol. Sci. 1(2): 1-8.

Savitha, R., T. Shasthree, Sudhakar and B. Mallaiah. 2010b. High frequency shoot bud organogenesis and plantlet regeneration from nodal explant of Citrullus colocynthis L. Schrad, an endangered medicinal cucurbit. Asian J. Exp. Biol. Sci. 1: $575-579$

Sawaya, W. N., N. J. Daghir and P. Khan. 1983. Chemical characterization and edibility of the oil extracted from Citrullus colocynthis seeds. J. Food Sci. 48: 104-106.

Schafferman, D., E. Shabelsky and Z. Yaniv. 2001. Citrullus colocynthis, an Israeli desert plant, as a potential source of edible oil. In: Pasternak, D. and A. Schlissel (Ed.), Combating Desertification with Plants, Springer Science Business Media, New York, pp. 161-167.

Sen, D.N. and M. C. Bhandari. 1974. On the ecology of a perennial cucurbit in Indian arid zone - Citrullus colocynthis (Linn.) Schrad. Int. J. Biometeorol. 18: 113-120.

Shaik, R. S., D. Gopurenko, N. A. R. Urwin, G. E. Burrows, B. J. Lepschi and L. A. Weston. 2015 Population genetics of invasive Citrullus lanatus, Citrullus colocynthis and Cucumis myriocarpus (Cucurbitaceae) in Australia: Inferences based on chloroplast and nuclear gene sequencing. Biol. Invasions. 17: 2475-2490.

Shasthree, T., R. Savitha and B. Mallaiah. 2009. Somaclonal variations in an endangered and medicinally important cucurbit, Citrullus colosynthis L. Res. J. Biotechnol. 5(2): 56-60.

Shasthree, T., C. Chandrashekar, R. Savitha and M. A. Imran. 2012. Effect of various plant growth regulators on callus induction from different explants of Citrullus colocynthis (L.) Schrad. Int. J. Univ. Pharm. Life Sci. 2(3): 33-39.

Shasthree, T., D. Ramakrishna, M. A. Imran and C. Chandrashekar. 2014. Adventitious shoot organogenesis and plant regeneration from leaf and cotyledon explants of Citrullus colocynthis. J. Herbs Spices Med. Plants. 20: 235-244.

Shimotsuma, M. 1960. Cytogenetical studies in the genus Citrullus, IV. Intra-and interspecific hybrids between C. colocynthis Schrad. and C. vulgaris Schrad. Jpn. J. Genet. 35(10): 303-312.

Si, Y., C. K. Zhang, S. S. Meng and F. Dane. 2009. Gene expression changes in response to drought stress in Citrullus colocynthis. Plant Cell Rep. 28: 997-1009.

Si, Y., Y. Huang, K. K. Kang and F. Dane. 2010a. Impact of grafting on NAC gene expression in Citrullus colocynthis and Citrullus lanatus during drought. Cucurbitaceae. 2010: 290-293.

Si, Y., F. Dane, A. Rashotte, K. Kang and N. K. Singh. 2010b. Cloning and expression analysis of the Ccrboh gene encoding respiratory burst oxidase in Citrullus colocynthis and grafting onto Citrullus lanatus (watermelon). J. Exp. Bot. 61: 1635-1642.

Taha, A. J. and H. H. Mutasher. 2014. In vitro callus induction and plantlet regeneration of bitter apple (Citrullus colocynthis). World J. Pharm. Pharm. Sci. 3(12): 86-96.

Teixeira da Silva, J. A. 2012a. Is BA (6-benzyladenine) BAP (6-benzylaminopurine)? Asian Australas. J. Plant Sci. Biotechnol. 6: 121-124.

Teixeira da Silva, J. A. 2012b. Callus, calluses or calli: Multiple plurals? Asian Australas. J. Plant Sci. Biotechnol. 6: 125-126.

Teixeira da Silva, J. A. and J. Dobránszki. 2013. Plant thin cell layers: A 40-year celebration. J. Plant Growth Regul. 32: 922-943.

Teixeira da Silva, J. A. and J. Dobránszki. 2014. Sonication and ultrasound: Impact on plant growth and development. Plant Cell Tissue Organ Cult. 117: 131-143.

Teixeira da Silva, J. A. and J. Dobránszki. 2015. How do magnetic fields affect plants in vitro? In Vitro Cell. Dev. Biol. Plant. 51: 233-240.

Teixeira da Silva, J. A., J. Dobránszki, J. C. Cardoso, S. F. Chandler and S. J. Zeng. 2016. Review: Methods for genetic transformation in Dendrobium. Plant Cell Rep. 35: 483-504.

Teixeira da Silva, J. A., G. B. Kerbauy, S. J. Zeng, Z. L. Chen and J. Duan. 2014. In vitro flowering of orchids. Crit. Rev. Biotechnol. 34: 56-76.

The Plant List. (2017) Citrullus colocynthis. Available from: http:// www.theplantlist.org/tpl1.1/search?q=Citrullus+colocynthis. [Last accessed on 2017 Jan 23].

Thimijan, R. W. and R. D. Heins. 1983. Photometric, radiometric, and quantum light units of measure: A review of procedures for interconversion. HortScience. 18: 818-822.

Verma, K. S., S. Kachhwaha and S. L. Kothari. 2013. In vitro regeneration of Citrullus colocynthis (L) Schrad and assessment of genetic fidelity using ISSR and RAPD markers. Indian J. Biotechnol. 12: 409-414.

Wang, Z. Y., A. M. Rashotte, A. G. Moss and F. Dane. 2014a. Two NAC transcription factors from Citrullus colocynthis, CcNAC1, CcNAC2 implicated in multiple stress responses. Acta Physiol. Plant. 36: 621-634.

Wang, Z. Y., A. M. Rashotte and F. Dane. 2014b. Citrullus colocynthis NAC transcription factors CCNAC1 and CcNAC2 are involved in light and auxin signaling. Plant Cell Rep. 33: 1673-1686.

Wang, Z., H. Hu, L. R. Goertzen, J. S. McElroy and F. Dane. 2014c. Analysis of the Citrullus colocynthis transcriptome during water deficit stress. PLoS One. 9: 104657. 